(C) 2019 Borysenko et al.. This article is distributed under the terms of CC Attribution-Share Alike 4.0 Internationalas described at https://creativecommons. org/licenses/by-sa/4.0

UDC: $37.02: 373.3(410)(043.3)$

DOI: $\underline{10.31499 /}$

\title{
FORMAT AND CONTENT OF PRIMARY CURRICULUM IN THE UNITED KINGDOM OF GREAT BRITAIN AND NORTHERN IRELAND: COMPARATIVE ANALYSES
}

\author{
Iryna Borysenko \\ PhD in Education, Head of Foreign Languages Chair, \\ Academy of the State Penitentiary Service, Chernihiv, Ukraine \\ ORCID: 0000-0002-1191-3126; e-mail: borisenko-irina@ukr.net \\ Oksana Bykonia \\ Doctor of Pedagogical Sciences, Professor of Foreign Languages Chair \\ Academy of the State Penitentiary Service, Chernihiv, Ukraine \\ ORCID: 0000-0002-8865-8792; e-mail: oksanabikonya@ukr.net \\ Tetiana Ihnatovych \\ Senior lecturer of Foreign Languages Chair, \\ Academy of the State Penitentiary Service, Chernihiv, Ukraine \\ ORCID: 0000-0002-6492-9519; e-mail: Ignatovichtetyana@gmail.com
}

Current reforms in the education systems in all European countries involve modernization of the education content in terms of implementation of new educational standards, programmes of study and textbooks, refining teaching approaches. It actualizes comparative studies in order to outline the achievements of European education and to define opportunities to use them in an innovative and efficient way in Ukrainian education.

The study aims to make comparative analyses of curriculum format and in four parts of the UK in order to outline areas of similarities and differences of the curriculum content in the UK. The study covers approaches to the designing of school curriculum in terms of programmes of study formulation (in accordance with natio-nal curriculum aims, community, school and pupils needs); planning a timetable; the number of terms in a year; lesson length, subject allocations, minimum time per subject per week, pupil groupings, additional hours for numeracy and literacy. The article illustrates how the schools are adapting their curriculum in light of current curriculum and education reforms. The article draws on evidence from a sample of primary schools in the UK, which provides an overview of how primary schools currently build, plan, implement, monitor and improve their curriculum. Key approaches to designing and structuring the curriculum content are also specified in the study. These are the principle of considering community and pupils' needs, educational traditions while forming the education content, practice-centred approach, resulting quality and the principle of flexibility.

Key words: curriculum format, designing, school curriculum, comparative analysis.

Сучасні осВітні реформи усіх ЄВропейсъких крайн передбачають модернізацію змісту освіти, зокрема, впровадження нових освітніх стандартів, оновлення навчальних програм $і$ підручників. Це актуалізує компаративні 
дослідження, мета яких полягає у виокремленні раціональних надбань зарубіж-ної школи та визначенні можливостей їх ефрективного і дочільного викорис-тання $b$ процесі розбудови українсъкої освіти.

Мета статті - здійснити порівняльний аналіз національних кури-кулумів чотирьох частин Сполученого Королівства задля виокремлення іх спільних $i$ відмінних характеристики. Дослідження охоплюе характеристику икільного курикулуму, а саме фрормату навчальних програм (з урахуванням мети начіонального курикулуму, потреб громади та учнів), укладання шкіль-ного розкладу, планування кільості семестрів на навчальний рік, визначення тривалості уроків, розподіл навчального часу між навчальними предметами, кількість годин відведених на вивчення предмету на тижденъ, розподіл додат-кових годин для навчання писемної грамотності $i$ математики; групування учнів. Наведено приклади того як школи адоптують свої курикулуми до вимог сучасних освітніх реформ, зокрема, планування, впровадження, оновлення шкільих курикулумів.

Визначені основні підходи до укладання шкільного курикулуму почат-кової освіти, а саме: баланс між чілями формування $b$ молодших школярів базових навичок i різнобічним розВитком особистості; врахування суспільних потреб, освітніх традицій $i$ запитів учнів у прочесі добору змісту освіти; практична спрямованість знань, навичок і вмінь; результативність, регіональна гнучкість).

Ключові слова: формат курикулуму, укладання, шкільнии курикулум, порівняльний аналіз.

The study draws on evidence from a sample of primary schools. The research considered how the schools are adapting their curriculum in the light of current curriculum and education reforms. It provides an overview of how primary schools currently evaluate, plan, deliver, monitor and refine their curriculum and teaching approaches. One of the most important elements of the new curriculum to be developed is making learning more experience-based. Nearly all of the visited schools take a positive approach to revising their school's curriculum

Introduction. The system of education in Ukraine is passing through a period of transformation turned into an innovative environment to build a system, which ensures that school graduates with obtained skills and knowledge can compete in the international labour market. The reforms involve modernization of the education content, implementation of new educational standards, of programmes of study.

It actualizes comparative studies in order to outline the achievements of European education and to define opportunities to use them in an innovative and efficient way in Ukrainian education. The experience of the United Kingdom of Great Britain and Northern Ireland in the modernization of education is of great interest. Since 2014 England and since 2018 Wales have seen some changes that resulted in implementing an ambitious new curriculum in primary education.

The study aims to make comparative analyses of curriculum design in four parts of the UK; to outline areas of similarities and differences of the curriculum content in the UK for educational policy in Ukraine.

Methodology. The comparative analysis comprises the following stages:

- collection and analysis of relevant documents of state agencies (Department of Education, Education Scotland, The Qualifications and Curriculum Development Agency (QCDA); Council for the Curriculum, Examinations and Assessment

- working out the algorithm for the analysis of curriculum designing in all parts of the UK; 
- analysis of the data and preparation of the comparative study;

- designing of comparative tables showing areas of similarities and differences in curriculum content in England, Wales, Northern Ireland and Scotland.

Result and Discussion. In the UK aims, values, subject content and skills defined on the national level outline the curriculum format and content, which varies across the four parts and concretizes in national standards. These are National Curriculum in England and Wales, Northern Ireland Curriculum and Curriculum for Excellence in Scotland. A national curriculum sets out the body of knowledge, skills and understanding that a community wants to pass on to their young people [1]. Schools in these four parts of the UK follow their own school curriculums set at the regional level, as national standards remain relatively prescriptive.

The school curriculum includes the National Curriculum and other statutory requirements, but schools have considerable freedom to determine the character and nature of their curriculums [2, p. 2]. School curriculum is used as a tool for process characteristics of the curriculum. Its designing refers to deciding on the following: programmes of study formulation (in accordance with national curriculum aims, community, school and pupils needs); planning a timetable; the number of terms in a year; lesson length, subject allocations, minimum time per subject per week, pupil groupings, additional hours for numeracy and literacy.

According to national curriculums in England, Wales and Northern Ireland (NI), primary education is divided into Key Stage 1 (KS 1) that covers years 1 and 2 in England and years 3 and 4 in NI (from when pupils start school to the age of seven or eight in NI) and Key Stage 2 that covers years 3-6 (ages seven to eleven) [3].

According to the new curriculum in Wales (2018), KS 1 has been replaced by the Foundation phase which is applied for learners aged from 3 to 7 [4, p. 11]. In England's Programmes of study for mathematics, English and science are designed for lower KS 2 (ages seven to nine) and upper KS 2 (ages nine to eleven) [5, p. 8]. Unlike all parts of the UK, in Scotland, there is no stage division in Curriculum for Excellence.

In England, Wales and Northern Ireland, there is a statutory subject-based national curriculum, from the age group 5 with some differences across these four parts. The national curriculums are structured around learning or curriculum areas comprising core subjects of English, mathematics and science and foundation subjects of art, geography, history, music, physical education and technology, modern foreign languages from age 7 (England) [6]. Scotland is the only part of the UK that doesn't specify subjects into core and foundation. The common feature uniting all national curriculums in the UK is grouping some subjects into curriculum areas (areas of learning and experience (AoLE) in Wales) under one heading, for example, history and geography are taught for a part of the key stages under the heading «social studies» (in Scotland), «the world around us» (in Northern Ireland), «knowledge and understanding the world» (in Wales) [7, p. 18]. It should be stressed that there is no common format for sets of subjects in the national curriculums of the four parts of the UK: they may have a different number of learning areas, different headings for learning areas and subjects they comprise. For example, in Wales curriculum has 6 areas of learning and experience: expressive arts; health and well-being, humanities; languages, literacy and communication; mathematics and numeracy; and science and technology.

Table 1 highlights learning areas at KS 1 and KS 2in England, Wales, Scotland and Northern Ireland [8, p. 7]. 


\begin{tabular}{|c|c|c|c|}
\hline England & Wales & $\begin{array}{l}\text { Northern } \\
\text { Ireland }\end{array}$ & Scotland \\
\hline Learning areas & $\begin{array}{c}\text { Areas of learning and } \\
\text { experience }\end{array}$ & $\begin{array}{l}\text { Areas of } \\
\text { learning }\end{array}$ & Curriculum areas \\
\hline \multicolumn{4}{|c|}{ Language } \\
\hline $\begin{array}{l}\text { English } \\
\text { Foreign } \\
\text { languages (from } \\
\text { age } 7, \text { from 2014) }\end{array}$ & $\begin{array}{l}\text { Languages, literacy and } \\
\text { communication English } \\
\text { Welsh }\end{array}$ & $\begin{array}{l}\text { Language and } \\
\text { literacy }\end{array}$ & $\begin{array}{l}\text { Languages } \\
\text { (Literacy, } \\
\text { English, Gaelic, a } \\
\text { foreign language }\end{array}$ \\
\hline \multicolumn{4}{|c|}{ Mathematics } \\
\hline Mathematics & $\begin{array}{l}\text { Mathematics and } \\
\text { numeracy }\end{array}$ & $\begin{array}{l}\text { Mathematics } \\
\text { and numeracy }\end{array}$ & $\begin{array}{l}\text { Mathematics } \\
\text { (including } \\
\text { numeracy) }\end{array}$ \\
\hline \multicolumn{4}{|c|}{ Social, environmental and scientific education } \\
\hline \multirow{4}{*}{$\begin{array}{l}\text { Science; } \\
\text { computing; } \\
\text { design and } \\
\text { technology; } \\
\text { geography; } \\
\text { history; } \\
\text { computing) }\end{array}$} & \multirow{3}{*}{$\begin{array}{l}\text { Humanities } \\
\text { (geography, history, RE, } \\
\text { social studies) }\end{array}$} & \multirow{4}{*}{$\begin{array}{l}\text { The world } \\
\text { around us } \\
\text { (geography, } \\
\text { history, science } \\
\text { and technology) }\end{array}$} & Sciences \\
\hline & & & Social sciences \\
\hline & & & Technology \\
\hline & $\begin{array}{l}\text { Science and technology } \\
\text { Designing and technology } \\
\text { Computer science }\end{array}$ & & \\
\hline
\end{tabular}

Continuation of Table 1

\begin{tabular}{|c|c|c|c|}
\hline \multicolumn{4}{|c|}{ Arts } \\
\hline $\begin{array}{l}\text { Art and design } \\
\text { music }\end{array}$ & $\begin{array}{l}\text { Expressive arts, } \\
\text { Music (creative } \\
\text { development to age } 7 \text { ) }\end{array}$ & $\begin{array}{l}\text { The arts, (art } \\
\text { and design, } \\
\text { music; drama) }\end{array}$ & Expressive arts \\
\hline \multicolumn{4}{|c|}{ Physical education (PE) } \\
\hline $\begin{array}{l}\text { Physical } \\
\text { education }\end{array}$ & $\begin{array}{l}\text { Health and well-being (PE, } \\
\text { sports) }\end{array}$ & $\begin{array}{l}\text { Physical } \\
\text { development } \\
\text { and movement }\end{array}$ & $\begin{array}{l}\text { Health and well- } \\
\text { being }\end{array}$ \\
\hline \multicolumn{4}{|c|}{ Social, personal and health education } \\
\hline $\begin{array}{l}\text { Personal, social } \\
\text { and health edu- } \\
\text { cation; Citizen- } \\
\text { ship (economic } \\
\text { education since } \\
\text { 2014) }\end{array}$ & & $\begin{array}{l}\text { Personal } \\
\text { education } \\
\text { mutual under- } \\
\text { standing (health } \\
\text { education) }\end{array}$ & $\begin{array}{l}\text { Health and well- } \\
\text { being }\end{array}$ \\
\hline \multicolumn{4}{|c|}{ Religious education (RE) } \\
\hline $\begin{array}{l}\text { Religious } \\
\text { education }\end{array}$ & & $\begin{array}{l}\text { Religious } \\
\text { education }\end{array}$ & $\begin{array}{l}\text { Religious and } \\
\text { moral education }\end{array}$ \\
\hline
\end{tabular}

The analysis of curriculums reveals that a set of subjects in national primary standards of four parts of the UK is more or less similar; almost all of the schools are moving towards a more real-life context. Some subjects and topics are renamed relating to new areas of learning and experience. There is an increasing tendency to develop a sense of pupils' identity. For example, a few schools in Wales choose themes that develop pupils' knowledge and understanding of history and culture of their country [9, p. 10]. Thus, curriculum areas provide the basis for learning and forming pupils' key skills and habits through cross- 
curriculum connection.

The national curriculum set out programmes of study to outline what pupils should be taught in each subject and attainment targets to guide teachers' assess-ment. Many schools in England have arrangements to implement the literacy and numeracy framework; digital competence and opportunities to develop genres of writing through cross-curricular work are added to the two cross-curriculum responsibilities in Wales [9, p. 10].

It should be stressed that cross-curriculum themes added to the framework of the national curriculum allow learners to develop their scientific outlook and motivate them to learn through interconnected topics. They aim to provide pupils' personal development, their creative thinking; to encourage the development of pupils' self-confidence and a sense of satisfaction with learning. In addition to subjects, schools should also teach religious education (with parental consent).

According to the National Strategy in Northern Ireland, numeracy and literacy is a major focus both across the curriculum and within the areas of learning [10, p. 12]. It should be mentioned that the new curriculum for Wales focuses on making learning more experience-based, developing pupils' critical thinking and problem-solving skills [4, p. 22]. Along with literacy and numeracy, Scotland's Curriculum for Excellence is intended to foster primary pupils' skills in reading for pleasure, confidence and fluency in moths [11].

In the UK entrepreneurship education is recognised as a priority at all edu-cation levels. In England, enterprise education is a part of learning area «personal, social and health education» and «economic wellbeing and financial capability». In Northern Ireland, enterprise education is taught within "personal development and mutual understanding» and «learning for life and work». In Scotland, enterprise education is recognised as a crosscurricular objective at all levels of school edu-cation. In Wales primary curriculum, entrepreneurship education is integrated into the subject «personal and social education» [12].

The abovementioned learning areas make up a primary education standard that takes up 85 per cent of all schooling hours in England and Wales and only 15 per cent go to the school component. In Scotland, the standard embraces from 70 to 80 per cent of all teaching hours, and the school component takes from 20 to 30 per cent [13, p. 13].

Most schooling hours are given to core subjects. For instance, in Scotland language, mathematics and science take from 50 to 52 per cent of schooling hours, and the rest of teaching time is distributed among other subjects of the national primary standard [14, p. 13].

In comparison with Scotland, the minimum number of the recommended hours defined in the Curriculum for Excellence (2007) at the primary stage of edu-cation is distributed among the curriculum areas as follows:

- languages, specifically native, and modern foreign language make up 20 per cent of the national primary standard;

- mathematics makes up 15 per cent;

- environment: science, society and technology make up 15 per cent;

- art and physical education make up 15 per cent;

- religious and moral education, personal, social and health education make up 15 per cent;

- the school component formed by the decision and with accordance to the needs of the school and local communities makes up 20 per cent [13, p. 24]

The standard of primary school in all regional parts across the UK comprises a relatively unified number of subjects, learning areas and cross-curriculum themes. The difference is the way how knowledge and skills are transmitted: either in a for-mat of separate subjects or integration into other disciplines on the cross-curriculum basis. The 
structure of the national curriculum in England, Wales and Northern Ireland includes programmes of study that set out subject content and skills for every subject at the corresponding stage of learning. It refers to the standard of the every subject content as programmes of study define the aim and objectives of every subject; describes the sequence of knowledge and concepts; specifies the nature, processes and teaching methods of each year group and attainment targets. A pro-gramme of study is made up of statutory requirements and non-statutory notes and guidance in every theme for every subject. Statutory requirements comprise a compulsory minimum of knowledge, skills and habits that pupils are to obtain by the end of the key stage. This material should be fully transmitted to pupils. The non-sta-tutory component includes the optional material content, methodical recommenda-tions as to the sources of the additional information for teachers and pupils. Schools are free to decide and choose methods, forms of teaching and textbooks [5, p. 8].

Since 2014 the concept has been changed into the other definition - «matters, skills and processes». The programmes of study in Northern Ireland include a similar form (knowledge, skills and habits). In the programmes of study of Wales the know-ledge to be transmitted is defined in «learning content», and attainment targets - in «the standards of pupils' learning achievements» [5, p. 25].

The content of new programmes of study in England that have been imple-mented since 2014 is more complicated, concrete and includes clearly defined know-ledge, rules, themes that should be learned.

The programmes of study defined by the Curriculum of the primary edu-cation in Northern Ireland take into consideration pupils' abilities to gain knowledge, skills and attitudes while learning subjects regarding their age and intelligence [15].

Unlike the programmes of study in England, Wales, Northern Ireland that define the compulsory and optional knowledge to be transmitted to pupils at every learning stage, the programmes of study in the Curriculum for Excellence in Scotland include only the recommendations for schools [16].

Following the aims of the national curriculum, every school designs their own school curriculum deciding following issues: school's priorities; additional needs of school and community; which subjects or aspects within them to be separately taught; what knowledge to be integrated into other subjects; the ways of adaptation of the curriculum to children with different abilities and needs; how to help pupils to proceed to the corresponding key stages of learning.

The issues of distribution of school component learning hours; the number of terms in a school year; the number of teaching hours, lesson length; the time allocated to subjects; extra hours for literacy and mathematics; the grouping of pupils are also defined by the school curriculum.

We suggest analysing school curriculums of the Suburban Junior School in the southern-eastern part of England and London Inner-City Primary School. A school year at both schools is divided into 3 terms and has 5 working days a week [17, p. 33]. Learning at both schools is organized in the form of separate school subjects. The geographical location of the first junior school determines the need to learn French in year 1 classes. To achieve this aim a school curriculum provides 2 lessons for 15 minutes a week in year 1 and two lessons for 20 minutes in year 2. In addition, the programme of study for French includes a one-day trip to France that promotes forming communication skills in a foreign language.

Besides English and Mathematics, another priority trend in the process of working out a school curriculum is geography and a cross-curriculum theme "per-sonal, social and health education» that helps to develop a pupil holistically and to form socially valuable skills. 
The form of knowledge transmission to pupils also varies. There are some approaches to lessons arrangement at primary school. The differences include the lesson length depending on a subject, stage of learning and time. Lessons can be combined in sessions or blocks. Table 2 presents how subjects and timing are organized for the first half of the summer term [17, p. 29].

Table 2

The timetable of the primary school for the first half of a summer term

\begin{tabular}{|c|c|c|c|c|c|c|}
\hline Time & Monday & Tuesday & Wednesday & Thursday & Friday & Length \\
\hline $8: 50$ & \multicolumn{5}{|c|}{ Registration (Spelling practice) } & 10 mins \\
\hline 9:00 & Science & English & $\begin{array}{l}\text { Mathe- } \\
\text { matics }\end{array}$ & $\mathrm{PE}$ & English & 60 mins \\
\hline 10:00 & $\begin{array}{l}\text { Mathe- } \\
\text { matics }\end{array}$ & $\begin{array}{l}\text { Mathe- } \\
\text { matics }\end{array}$ & English & $\begin{array}{l}\text { Mathe- } \\
\text { matics }\end{array}$ & $\begin{array}{l}\text { Mathe- } \\
\text { matics a }\end{array}$ & 50 mins \\
\hline 10:50 & \multicolumn{5}{|c|}{ Break } & 15 mins \\
\hline 11:05 & English & $\begin{array}{l}\text { Religious } \\
\text { education }\end{array}$ & Science & English & Drama & 70 mins \\
\hline 12:15 & \multicolumn{5}{|c|}{ Lunch } & 60 mins \\
\hline 13:15 & \multicolumn{5}{|c|}{ Registration (5 mins) and mathematics or reading } & 10 mins \\
\hline $13: 25$ & $\begin{array}{l}\text { History / } \\
\text { ICT }\end{array}$ & Music & English & $\begin{array}{l}\text { Geo- } \\
\text { graphy }\end{array}$ & $\begin{array}{l}\text { Art and } \\
\text { Design/ } \\
\text { ICT }\end{array}$ & 50 mins \\
\hline 14:15 & $\begin{array}{l}\text { Історія / } \\
\text { ICT }\end{array}$ & PE & English & $\begin{array}{l}\text { Geo- } \\
\text { graphy }\end{array}$ & $\begin{array}{l}\text { Art and } \\
\text { Design/ } \\
\text { ICT }\end{array}$ & 50 mins \\
\hline $\begin{array}{l}15: 05 \\
15: 20\end{array}$ & $\begin{array}{l}\text { Junior } \\
\text { assembly } \\
\text { The end of } \\
\text { the working } \\
\text { day }\end{array}$ & $\begin{array}{l}\text { Junior } \\
\text { assembly }\end{array}$ & $\begin{array}{l}\text { Class } \\
\text { assembly }\end{array}$ & $\begin{array}{l}\text { Year } \\
\text { group } \\
\text { assembly }\end{array}$ & $\begin{array}{l}\text { Whole } \\
\text { school } \\
\text { assembly }\end{array}$ & 15 mins \\
\hline
\end{tabular}

As the timetable is overloaded, spelling practice, foreign languages learning, consolidation of themes in mathematics can be organized during pupils' morning registration. Most subjects are taught separately. The structure of a timetable has timed literacy and maths lessons into «50-, 60-, 70-minute slots». The list of subjects is not the same for each term. For example, design and technology may not be taught in the half term. Elements of ICT are integrated into history and art or design.

In order to follow the principle of coherence organization of learning at primary schools of Northern Ireland is made up in blocks. For instance, 48 hours are given for a native language for 12 weeks. This makes possible to integrate the development of speaking, reading and writing skills, into the pupils' out-of-class activities, into other learning areas on a more constant basis; to plan out-of-class activities (for example visits to a library) [17, p. 20].

Teachers are free to adapt the curriculum for pupils' needs, to enlarge pupils' choice and opportunities. A major characteristic of the Curriculum for Excellence: the implementation of the set of «Experiences and Outcomes»; value component; personal support; rights and opportunities, assessment, self-assessment [18].

Among basic knowledge that pupils must have the programme of study for every subject contains the recommendations concerning the development of key skills that are very important in the context of a practice-centred approach in education. Table 4 shows 
the framework or statements relating to key skills pupils should develop for life and work [5, p. 23; 19].

Table 3

\section{Key Skills in national curriculums of England, Wales, Scotland and Northern Ireland}

\begin{tabular}{|c|c|c|c|}
\hline England & Wales & Northern Ireland & Scotland \\
\hline $\begin{array}{l}\text { Cross-curricular } \\
\text { literacy and } \\
\text { numeracy skills } \\
\text { Knowledge, skills and } \\
\text { understanding } \\
\text { (matters, skills and } \\
\text { processes from } \\
\text { Cross-cutting } \\
\text { development of } \\
\text { pupils' competence in } \\
\text { numeracy and } \\
\text { mathematics, and } \\
\text { language and literacy }\end{array}$ & $\begin{array}{l}\text { Cross-curriculum } \\
\text { responsibilities } \\
\text { Literacy and numeracy } \\
\text { framework: developing } \\
\text { skills and confidence in } \\
\text { learners that make them } \\
\text { adaptable to changes in } \\
\text { technology over time. } \\
\text { Digital Competence } \\
\text { Framework: } \\
\text { Communicating, } \\
\text { collaborating, problem- } \\
\text { solving and handling } \\
\text { online bullying }\end{array}$ & $\begin{array}{l}\text { Cross-curricular skills } \\
\text { - communication } \\
\text { - using mathematics } \\
\text { - using ICT } \\
\text { Other skills } \\
\text { - being creative } \\
\text { - working with others } \\
\text { - self-management } \\
\text { - managing } \\
\text { information } \\
\text { - thinking, problem- } \\
\text { solving and decision } \\
\text { making }\end{array}$ & $\begin{array}{l}\text { The four capacities of } \\
\text { Curriculum for } \\
\text { Excellence (successful } \\
\text { learners, confident } \\
\text { individuals, } \\
\text { responsible citizens, } \\
\text { effective contributors) } \\
\text { Health and well- } \\
\text { being, literacy across } \\
\text { learning, numeracy } \\
\text { across learning } \\
\text { Self-management - } \\
\text { encouraging pupils to } \\
\text { become self-directed, } \\
\text { evaluate their own } \\
\text { strengths and } \\
\text { weaknesses, identify } \\
\text { their interests and } \\
\text { attitudes to learning }\end{array}$ \\
\hline
\end{tabular}

Conclusions. To sum up the material, we should give the key principles of designing and structuring the curriculum content. First of all, this is the principle of considering community and pupils' needs, educational traditions while forming the education content, the principle of practice-centred approach, the principle of resulting quality, the principle of flexibility. In particular, implementation of learning areas and cross-curriculum themes is aimed at primary pupils' key skills forming (that are actually similar to the key competencies in other European countries) and this is a response to the strategic focus of the European Union in building the society of knowledge.

Implementation of the block of the expected results meets the trend of making education competitive and effective in the use of costs invested in it. The principle of flexibility makes it possible to take into account the regional peculiarities of all parts of the United Kingdom. The existence of several national curriculums that are based on the common features of designing (the list of key skills, expected results, basic school subjects) but are different in the part that concerns the organization of learning and cross-curriculum themes.

Differences in the curriculum content of different parts of the UK include the following: the absence of division of subjects into core and foundation; into key stages in Scotland; the emphasis of national curriculum of Northern Ireland and Scotland on forming skills connected with independent activities in future life that is correlated with the content of cross-curriculum themes; implementation of value and some personal support components into Curriculum for Excellence in Scotland.

References: 
united-kingdom.

2. Key Stage 3. National strategy. Designing the Key stage 3 curriculum. DfES Publications: Crown copyright, 2010, P. 2.

3. UK Education System Guide 2019 - Everything You Need to Know. Available at: https://www.studying-inuk.org/uk-education-system-guide.

4. Our National Mission: a Transformation Curriculum - Proposals for a new legislative framework (2019), Welsh Government. Consultation Document, 2019. - 61 p.

5. Grayson, H, Houghton, E, O'Donnell, S, Sargent, C. (2014). Curriculum Structures and Stages in Primary Education: Audit of Policy Across Jurisdiction: Key Findings Summary. Slough: NFER (National Foundation for Education Research).

6. Curriculum of United Kingdom. Available at: https://www.slideshare.net/haniakhan90857901/curri culum-ofunited-kingdom.

7. NFER (National Foundation for Education Research. Curriculum Structures and Stages in Primary Education Audit of Policy Across Jurisdiction: Key Findings Summary (2014). London: NFER.

8. Roberts, N. (2018). The School Curriculum in England., House of Commons Library, Briefing paper, 16 April 2018.

9. Curriculum innovation in primary schools. Thematic survey report, May 2018, Wales: Estyn.

10. Literacy and Numeracy for Learning and Life (2011). The National Strategy to Improve Literacy and Numeracy among Children and Young People 2011-2020, Dublin: Department of Education and Skills.

11. School curriculum and qualifications. Scottish government (2018). Available at: https://www.gov. scot/policies/schools.

12. Entrepreneurship education in the United Kingdom. Available at: https://www.schooleducationgate way.eu/downloads/entrepreneurship/United\%20Kingdom_151022.pdf.

13. Metais, J. (2003). International Trends in Primary Education. INCA Thematic Study No. 9. London: Qualification and Curriculum Authority.

14. NCCA. (2010). National Council for Curriculum and Assessment. Curriculum Overload in Primary Schools: An Overview of National and International Experience. February 2010. London: Crown.

15. INCA. Education around the World. Northern Ireland: Curricula (Age 2-19). 5.2. Second Phase: compulsory primary education, 4-to 11-year-olds. London: INCA, QCA, NFER. Available at: http:// www.inca.org.uk/1304.html.

16. INCA. Education around the World. Scotland: Assessment Arrangements. 6.2. Second Phase: Compul-sory primary education, ages 5-12. London: INCA, QCA, NFER. Available at: http://www.inca.org. uk/1191.html.

17. Designing and Timetabling the Primary Curriculum (2009). A Practical Guide for Key Stages 1 and 2: Guarding Standards. London: Qualifications and Curriculum Authority.

18. Curriculum for Excellence. Smarter Scotland: Improving Scottish education. Scottish Government Available at: www.curriculumforexcellencescotland.gov.uk

19. The New Curriculum for Wales-What we are doing in St Monica's July 2018. Available at: http://www.stmonicasschool.co.uk/news/detail/new-curriculum-for-wales-parent-help-sheet 